\title{
Randomness of Stock Return in Nigerian Banking Sector
}

\author{
OBISESAN Oluwaseun G. ${ }^{1} \rtimes$ \\ AJAYI Boboye L. ${ }^{2}$ \\ ${ }^{1,2}$ Department of Banking and Finance, Faculty of Management Sciences, Ekiti State University, Ado Ekiti, \\ Nigeria
}

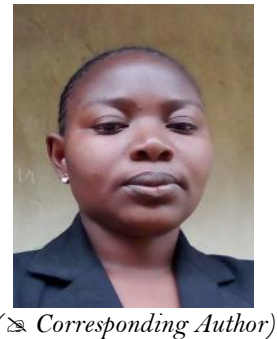

\begin{abstract}
This study presents a test of Random Walk Hypothesis in the Nigerian Stock Market, with a view to determining if stock price changes conform to predetermined probability distribution. A sample of thirteen Deposit Money Banks which are listed on the Nigerian Stock Exchange between 2007 and 2014 were used in the analysis. Secondary daily price data for the period were sourced from the capital assets section of NSE Fact Book. The methods used were; Augmented Dickey-Fuller Test (ADF), Phillips-Perron Test (PP) and Kwiatkowski, Phillips, Schmidt and Shin Test (KPSS) unit root tests were used to test non-stationarity while Descriptive Statistics of Jaque-bera were used to check for normality. The ADF, PP and KPSS unit root test results imply that the changes in stock prices are stationary at level while Descriptive statistics results indicate that the changes in stock prices do not follow a normal distribution. The findings of this study show that stock price changes are stationary and not normally distributed. Based on the findings, the changes in Nigerian Deposit Money banks' stock price in Nigerian stock exchange do not follow a random walk. In other words, Nigerian Stock market is not weak form efficient. The study recommends that since changes in stock prices are not indeterminable or caused by random events, the investor should endeavour to identify what determines the prices in the past in order to ensure judicious and prudent allocation of their investable funds.
\end{abstract}

Keywords: Random walk, Deposit money bank, Daily stock return, ADF, KPSS

Citation | OBISESAN Oluwaseun G.; AJAYI Boboye L. (2017). Randomness of Stock Return in Nigerian Banking Sector. Asian Journal of Economics and Empirical Research, 4(2): 99-105. History:

Received: 4 May 2017

Revised: 12 October 2017

Accepted: 27 October 2017

Published: 30 October 2017

Licensed: This work is licensed under a Creative Commons

Attribution 3.0 License $(\mathrm{cc}) \mathbf{E}$

Publisher:Asian Online Journal Publishing Group
Contribution/Acknowledgement: Both authors contributed to the conception and design of the study.

Funding: This study received no specific financial support.

Competing Interests: The authors declare that they have no conflict of interests.

Transparency: The authors confirm that the manuscript is an honest, accurate, and transparent account of the study was reported; that no vital features of the study have been omitted; and that any discrepancies from the study as planned have been explained.

Ethical: This study follows all ethical practices during writing.

\section{Contents}

1. Introduction

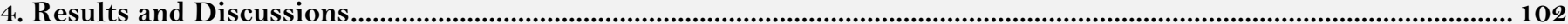

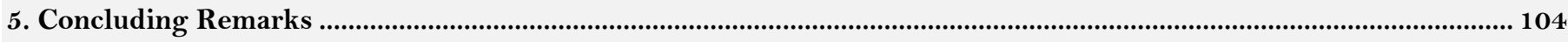

References...

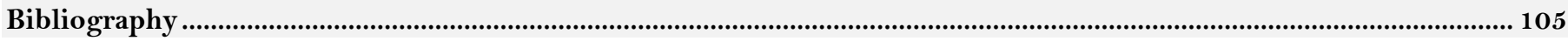




\section{Introduction}

Whenever money is put into any investment, the expectation of such investor is profit in form of return. In the same vein, an investor in the stock market has expectation of generating a profit on the capital invested. Market efficiency, championed in the Efficient Market Hypothesis (EMH) was formulated by Fama in 1965. It suggests that at any given time, prices fully reflect all accessible information on a particular stock in a given market. Thus, according to the EMH, no investor has an advantage in predicting a return on a stock price because no one has access to information not already available to anyone else. In efficient markets, prices turn out to be not predictable but random in nature, so no investment pattern can be discerned. A planned approach to investment therefore, is not possible.

Stock market efficiency has significant implication for these investors as well as the regulatory authorities. A lot of investors attempt not only to make a profitable return, but also to beat the market. Random Walk of prices, commonly spoken about in the efficient market hypothesis school of thought results was due to the collapse of any investment strategy that aims to outperform consistently. In Nigeria, the validity of random walk hypothesis has attracted the attention of researchers in the recent years. The empirical evidences such as Aktham (2003) and Samuel (2007) for developing countries, Graham and Hyun-Jung (2003) for a developed country, Godwin (2010) and Mojekwu and Ogege (2013) in Nigeria, etc. produce mixed results. In view of this, the question still remains; are present stock prices dependent on past stock prices in Nigeria Stock Market? And do changes in stock prices in Nigeria Stock Market conform to some probability distribution? It is in an attempt to answer these questions that the study is set out with a view to contribute to the ongoing debate. The fundamental objective of this study, therefore, is to examine the weak-form efficiency of Nigerian Stock Exchange. Specifically the study intends to determine if stock price changes conform to predetermined probability distribution in the Nigerian Stock Market.

The rest of the Paper is organized in to three sections, namely the review of existing literature; the research method; results and discussion and the conclusion and recommendation.

\section{Literature Review}

Randomness means something that is dynamic in nature or not steady/static. It is the trend of events, a movement of an object that occurs spontaneously and unpredictably. It is synonymous with the movement of a drunkard whose steps are uncoordinated and irrational and therefore, unpredictable (Joel and Sunday, 2015).

Random walk hypothesis postulate that successive price changes in individual securities are independent random variables. According to Fama (1965) and Kendall (1953) in a random walk market, stock prices fluctuate randomly around their intrinsic values, return quickly towards the equilibrium and fully reflect the latest information available in the market. Although the price adjustments may be imperfect, it is unbiased; meaning that sometimes the market will over- adjust and other times it will under-adjust, but it cannot be predicted which one will occur at any given time.

According to Bodie et al. (2009) because security prices adjust to all new information the security prices should reflect all information that is publicly available at any point in time. The security prices that prevail at any time should be an unbiased reflection of all currently available information, including the risk involved in owning the security. The combined effect of information coming in a random, independent, unpredictable fashion and numerous competing investors adjusting stock prices rapidly to reflect this new information is that one would expect price changes to be independent and random. Random walk hypothesis shows that prices of shares and stocks are not stable due to the fact that future prices cannot be determined by previous prices (today's price does not depend on yesterday i.e. stock prices are independent). As new information become available the price of the stock also changes. The theory of random walks in stock prices actually involves two separate hypotheses. The hypothesis which the study aimed at testing is whether the changes in stock prices conform to some probability distribution.

Graham and Hyun-Jung (2003) evaluated the random walk hypothesis for European emerging stock markets, using the multiple variance ratio tests. It was discovered that the stock market price does not follow random walk hypothesis. Worthington and Higgs (2004) tests for random walks and weak-form market efficiency in European equity markets. Combination of serial correlation coefficient and runs tests, Augmented Dickey-Fuller (ADF), Phillips-Perron (PP) and Kwiatkowski, Phillips, Schmidt and Shin (KPSS) unit root tests and multiple variance ratio (MVR) tests were analyzed. The result indicated that from the emerging markets, only Hungary is characterized by a random walk and hence is weak-form efficient, while in the developed markets only Germany, Ireland, Portugal, Sweden and the United Kingdom comply with the most stringent random walk criteria.

Am'elie and Olivier (2009) examined the random walk hypothesis for Chinese stock markets using variance ratio tests. The study examines the random walk hypothesis for the Shanghai and Shenzhen stock markets for both $\mathrm{A}$ and B shares. The hypothesis is tested with new multiple variance ratio tests. It was found that Class B shares for Chinese stock exchanges do not follow the random walk hypothesis, and therefore are significantly inefficient while the Class A shares seems more efficient. Kavalerchik (2011) investigated the Random Walk Hypothesis based on Stock Prices, Dividends, and Earnings. The Augmented Dickey-Fuller (ADF) test for unit roots, while the data for the assorted indices and stocks date back to various dates, all data used end on October 1, 2009. The finding suggested that earnings data have some predictability for stock prices.

Hussain et al. (2011) for the period from January 2006 to December 2010 studied Karachi Stock Exchange for Day of the week effect and stock returns by using time series (regression equation), ANOVA test as research methodology. They concluded that investor gets constant returns for the six days out of seven days of the week, only the Tuesday has significant impact on the Pakistani Stock Markets which results in abnormal returns for the investors. Aktham (2003) evaluated the random walk hypothesis in the Amman (Jordan) Stock Exchange. OLS, Arch and Garch, Jargue Bera normality and nonlinearity test were used to run the daily data collected. The study found that daily returns from the Amman (Jordan) Stock Exchange do not conform to a random walk. Samuel (2007) studied why share prices might follow a Random Walk. Empirical evidence is used to investigate the arguments for and against the model. It was discovered that the Efficient Markets Hypothesis no longer holds the 
impervious position in finance it once did; consequently the assumption that share prices follow a random walk is now uncertain.

In a comparative analysis of India and Pakistan stock markets, Ishaq et al. (2014) use adjusted daily prices descriptive statistics, ADF test, Auto-Correlation test and Jarque-Bera Statistic, Runs test to analyze the data for the period ranging between 2003 and 2013. The study found out that the stock markets of both economies are not efficient in weak form. Bhanu and Bishnoi (2005) test Random Walk Hypothesis for Indian stock market indices. The indices have been tested for normality, autocorrelation using Q-statistic \& Dickey-Fuller test and analyzed variance ratio using homoscedastic and heteroscedastic test estimates. The results support that Indian stock market indices do not follow random walk. Godwin (2010) studied the stock market prices and random work hypothesis in Nigeria. Autocorrelation and run test were used to analyze the data. The results of the three tests show the evidence of weak form efficiency and a confirmation of random walk. Also, that successive price changes are not dependent.

Nwosa and Osheni (2011) examined efficient market hypothesis and Nigeria stock market using PP, ADF, autocorrelation and regression methods. The correlation results shows that successive daily price changes tend to have the same sign hence the Nigerian Stock Market is informational inefficient. More so, the previous stock prices are statistically significant in determining the current. Mojekwu and Ogege (2013) carried out econometric investigation of the random walk hypothesis in the Nigerian Stock Exchange. Ordinary Least Square method, correlation matrix, ADF and PP were adopted in analyzing the data collected. It was found, inefficiency in price determination and opportunity for some investors to earn abnormal profit, hence the absence of random walk.

Afego (2012) tests the random walk hypothesis for the Nigerian all share monthly index returns using the nonparametric runs test and goodness of fit test over the period 1984 to 2009. The results from this study suggest that stock price changes on the NSE are not random and that according to Technicalist, exploitable patterns exist, making it possible for arbitrage portfolios to be constructed based on trading rules and making sub-optimal allocation of investable funds within the economy a possibility. Market inefficiencies is a feature of Nigerian stock market. Ajao and Osayuwu (2012) tested the weak form of efficient market hypothesis in Nigeria Capital Market. Auto-correlation test and runs test was used in analyzing the data collected. The study reveals that the Nigeria Capital Market is efficient in the weak form due to the prerequisite for a weak form of efficient market. Also, that the past and future prices of stock market are independent.

Osisanwo and Atanda (2012) carried out a time series analysis of the determinants of stock market returns in Nigeria using Ordinary Least Square. From the study, it can be found that external shock and other macroeconomic variables dictate the movement of stock market prices performance. Nwidobie (2014) carried out empirical investigation of the random walk theory in the Nigerian Capital Market. ADF and Unit root model was used to run the analysis. It was discovered that random walk hypothesis is not supported by findings in Nigerian Capital Market. Also, there exists market inefficiency in the market. Victor (2010) tested the weak-form efficiency market hypothesis in Nigerian Stock Market. Auto correlation tests and run test was adopted in the analysis and the finding reveals that stock market is inefficient in the weak form. Also, Emeh and Obi (2014) evaluated the weak form of efficient market hypothesis from Nigeria. Unit Root test and Johnason co-integration test, the finding shows that there exist random walk model revealing inefficiency in the weak form of the market. Yacout and Samuels (1981) tested the correlation of weekly prices of 21 companies quoted at the Nigerian Stock Exchange (NSE). The result revealed that the price follow a random walk thus confirming the efficiency of the market.

\section{Research Method}

According to Fama (1965) one of the main hypotheses of Random Walk is that successive price changes conform to some probability distribution.

\subsection{Model Specification}

The study adopts the random walk model of Lo and MacKinlay (1988) which is specified as follows: $\mathrm{SP}_{\mathrm{t}}=f\left(\mathrm{SP}_{\mathrm{t}-1}\right)$

$\mathrm{SP}_{\mathrm{t}}=\delta+\alpha \mathrm{SP}_{\mathrm{t}-1}+\mu$

Where:

$\delta=$ constant

$\alpha=$ coefficient of past stock price

$\mathrm{SP}_{\mathrm{t}}=$ present stock price

$\mathrm{SP}_{\mathrm{t}-1}=$ past stock price

$\mu=$ stochastic error term

On a priori, changes between present stock price and past stock price are expected to be non-stationary and normally distributed.

\subsection{Estimation Technique}

In this study, the statistical tests that are employed include Descriptive statistic, Unit root test, Autocorrelation test and Variance Ratio tests to determine the dependency among successive stock price changes.

\subsection{Unit Root Tests}

Unit root is a necessary condition for random walk. Here series of changes in stock prices are expected to have unit root (non-stationary). For a test of unit root, the study employs Augmented Dickey-Fuller, Phillips-Perron Tests and KPSS. 


\subsection{Augmented Dickey-Fuller Tests}

This test will be used to achieve the second objective of the study. The time series variables characteristics and order of stationarity will be determined using the ADF and PP unit root tests developed by Phillips and Perron (1988). This is based on the following model:

$$
\begin{gathered}
\Delta Y_{t}=\beta_{1}+\delta Y_{t-1}+\sum_{\tau=1}^{m} \alpha_{i} \Delta Y_{t-1}+\varepsilon_{t} \quad \text { (with intercept) } \\
\Delta Y_{t}=\beta_{1}+\beta_{2} t+\delta Y_{t-1}+\sum_{\tau=1}^{m} \alpha_{i} \Delta Y_{t-1}+\varepsilon_{t} \quad \text { (with trend and intercept) }
\end{gathered}
$$

Where $Y_{t}$ represents the values of each variable in the two equations. The t-statistics was used to test the null hypothesis of $1=0$ (i.e. no stationary) against the alternative that $1<0$ (i.e. stationary). If the series were not stationary at level, i.e. I(O), it would be differenced $\boldsymbol{d}$ times to be stationary and to determine its order of integration. i.e $\mathrm{I}(1)$ or $\mathrm{I}(2)$

\subsection{Phillips-Perron Test}

The PP estimates the non-augment DF test. The PP is based on the statistic;

$$
\tilde{\mathrm{u}} t_{\propto}=t_{\propto}\left(\frac{Y_{o}}{f_{o}}\right)^{1 / 2}-\frac{T\left(f_{o}-Y_{o}\right) \operatorname{Se}(\propto)}{2 f_{o 1 / 2 S}}
$$

where $(\propto)$ is the estimate, and $t_{\propto}$ the $t$-ratio ratio of $\propto, S e(\propto)$ is coefficient standard error, and $S$ is the standard error of the test regression. In addition, $Y_{O}$ is a consistent estimate of the error variance in the equation. $\left\{\right.$ Calculated as $\left(\frac{[T-K] S^{2}}{T}\right)$, where $K$ is the number of regressors). The remaining term, $f_{o}$ is an estimator of the residual spectrum at frequency zero.

\subsection{Kwiatkowski, Phillips, Schmidt and Shin Test (KPSS)}

KPSS differs from other unit root tests in that the series $y_{t}$ is assumed to be trend stationary under the null hypothesis such that:

the statistic is being defined as:

$$
y_{t}=x_{t}^{\prime} \delta+\tilde{u}_{t}
$$

$$
\mathrm{LM}=\sum_{t}\left(\frac{s(t)^{2}}{T_{f_{o}}^{2}}\right)
$$

Where $f_{o}$ is an estimator of the residual spectrum at frequency zero and where $S(t)$ is a cumulative residual function.

\subsection{Description of Data and Sources}

The data used in this study are described as follows:

$\mathrm{SP}_{\mathrm{t}}=$ Stock price at time it is used to describe present change in stock (i.e. Price today minus price yesterday) such that:

ACCE $=$ today - yesterday stock price of Access bank

FIDE $=$ today - yesterday stock price of Fidelity bank

$\mathrm{FCMB}$ = today - yesterday stock price of FCMB bank

GTBB today - yesterday stock price of GTB

STAM today - yesterday stock price of Stanbic IBTC bank

SKYE = today - yesterday stock price of Skye bank

STER = today - yesterday stock price of Sterling bank

$\mathrm{UBAB}=$ today - yesterday stock price of UBA bank

$\mathrm{UNIO}=$ today - yesterday stock price of Union bank

$\mathrm{UNIT}=$ today - yesterday stock price of Unity bank

WEMA = today - yesterday stock price of Wema bank

ZENI = today - yesterday stock price of Zenith bank

$\mathrm{SP}_{\mathrm{t}-1}=$ is the present stock price lagged by one period. It is used to represent past stock price changes i.e. (Price yesterday minus price day before yesterday). These data are obtained from secondary sources, namely the Capital Asset Section of NSE Fact Book

\section{Results and Discussions}

A stock market is believed to follow a random walk if changes in stock prices is non-stationary and of normal distribution. The results of the descriptive analysis used to ascertain the normality of stock price changes is presented in Table 1.

Table 1 shows the descriptive statistics of the data series used in the current study. ACCE averaged 0.0002and vary from a minimum of -1.4 to a maximum of 1.2. DIAM, FIDE, FCMB, GTBB, STAM, SKYE, STER, UBAB, UNIO, UNIT, WEMA and ZENI. has a mean of 0.0012, 0.00029, 0.00088, 0.00338, 0.00234, 0.012125, 0.00077, $0.0118,0.00784,0.00133,0.00121$ and 0.00326 ranges from a minimum of $-22.86,-13.79,-4.75,-11.88,-10.02,-$ $16.38,-2.32,-19.17,-12.6,-5.59,-13.4$ and-23.45 to a maximum of $22.76,22.51,4.6,13.38,8.95,17.49,2.26,6.44$, $9.47,5.32,13.4$ and 13.72 respectively. The $p$-value of Jarque-Bera statistics are less than $5 \%$ which implies a rejection of null hypothesis of normality at $1 \%$ significance level. It means that ACCE, DIAM, FIDE, FCMB, GTBB, STAM, SKYE, STER, UBAB, UNIO, UNIT, WEMA and ZENI are not normally distributed. The statistics for Kurtosis shows that DIAM, FIDE, FCMB, GTBB, STAM, SKYE, STER, UBAB, UNIO, UNIT, WEMA and ZENI are leptokurtic since their distribution are peaked relative to normal. The statistics for skewness 
shows that all ACCE, DIAM, FCMB, GTBB, UBAB, UNIO, WEMA and ZENI were negatively skewed while FIDE, STAM, SKYE, STER, and UNITY are positively skewed.

Table-1. Descriptive Statistics

\begin{tabular}{l|l|l|l|l|l|l|l|l|l}
\hline & Mean & Maxi & Mini & Std. Dev. & Skewness & Kurtosis & Jarque-Bera & rob & Observ. \\
\hline ACCE & -0.00021 & 1.2 & -1.4 & 0.289114 & -0.13035 & 5.868646 & 652.3593 & 0.00 & 1887 \\
\hline DIAM & -0.0012 & 22.76 & -22.86 & 0.803235 & -0.11285 & 690.9823 & 37214760 & 0.00 & 1887 \\
\hline FIDE & -0.00029 & 22.51 & -13.79 & 0.825933 & 10.10152 & 416.2998 & 13462555 & 0.00 & 1887 \\
\hline FCMB & -0.00088 & 4.6 & -4.75 & 0.297327 & -0.54223 & 95.72956 & 676170.8 & 0.00 & 1887 \\
\hline GTB & 0.003381 & 13.38 & -11.88 & 0.741046 & -0.10617 & 103.6356 & 796280 & 0.00 & 1887 \\
\hline STAM & -0.00234 & 8.95 & -10.02 & 0.491746 & 0.961407 & 195.6611 & 2918717 & 0.00 & 1887 \\
\hline SKYE & 0.012125 & 17.49 & -16.38 & 0.786781 & 0.630416 & 295.4806 & 6726091 & 0.00 & 1887 \\
\hline STER & -0.00077 & 2.26 & -2.32 & 0.139317 & 0.295989 & 99.87715 & 737937.5 & 0.00 & 1887 \\
\hline UBAB & -0.0118 & 6.44 & -19.17 & 0.742066 & -9.28936 & 251.389 & 4878075 & 0.00 & 1887 \\
\hline UNIO & -0.00784 & 9.47 & -12.6 & 0.737305 & -2.50881 & 100.2811 & 746056.7 & 0.00 & 1887 \\
\hline UNIT & -0.00133 & 5.32 & -5.59 & 0.276318 & 4.354445 & 254.5712 & 4981986 & 0.00 & 1887 \\
\hline WEMA & -0.00121 & 13.4 & -13.4 & 0.645295 & -0.20856 & 371.1329 & 10655420 & 0.00 & 1887 \\
\hline ZENI & -0.00326 & 13.72 & -23.45 & 1.082186 & -5.33067 & 185.0033 & 2613406 & 0.00 & 1887 \\
\hline Sourc:
\end{tabular}

Source: Author's computation (2016)

\subsection{Unit Root Tests}

Since a unit root is a necessary condition for a random walk, the Augmented Dickey-Fuller test is used to test the null hypothesis of a unit root. The results of Augmented Dickey-Fuller for a unit root in stock price changes are presented in Table 2 .

Table-2. Unit Root Test: ADF

\begin{tabular}{l|l|l|l|l}
\hline Variables & ADF Test Statistics & Makinnon Critical Value @ 5\% & Prob. & Conclusion \\
\hline ACCES & -36.75468 & -2.862869 & 0.0000 & Reject \\
\hline DIAM & -33.31875 & -2.862871 & 0.0000 & Reject \\
\hline FIDE & -31.26660 & -2.862871 & 0.0000 & Reject \\
\hline FCMB & -47.21351 & -2.862869 & 0.0001 & Reject \\
\hline GTBB & -41.69622 & -2.862869 & 0.0000 & Reject \\
\hline STAM & -39.93105 & -2.862869 & 0.0000 & Reject \\
\hline SKYE & -37.27772 & -2.862870 & 0.0000 & Reject \\
\hline STER & -44.45369 & -2.862869 & 0.0001 & Reject \\
\hline UBAB & -37.66112 & -2.862869 & 0.0000 & Reject \\
\hline UNIO & -41.53341 & -2.862869 & 0.0000 & Reject \\
\hline UNIT & -19.79650 & -2.862872 & 0.0000 & Reject \\
\hline WEMA & -35.10079 & -2.862871 & 0.0000 & Reject \\
\hline ZENI & -51.04354 & -3.433617 & 0.0001 & Reject \\
\hline Source: Author's Computation $(2016)$ & &
\end{tabular}

The hypothesis for the ADF is that the null hypothesis claims that a unit root is present (i.e series are not stationary). The more negative the test statistic is, the stronger is the probability of rejecting the null hypothesis; that there is a unit root at the given level of confidence. Table 4.3.1 shows that the test statistics are all above the critical limits at $5 \%$, for $\operatorname{ACCE}(36.75468>2.862869)$, DIAM $(33.31875>2.862871)$, FIDE $(31.26660>2.862871)$, $\operatorname{FCMB}(47.21351>2.862869), \operatorname{GTBB}(41.69622>2.862869), \quad \operatorname{STAM}(39.93105>2.862869)$, $\operatorname{SKYE}(37.27772>2.862870), \quad \operatorname{STER}(44.45369>2.862869), \operatorname{UBAB}(37.66112>2.862869), \operatorname{UNIO}(41.53341>$ 2.862869), $\operatorname{UNIT}(19.79650>2.862872)$, $\operatorname{WEMA}(35.10079>2.862871)$ and $\mathrm{ZENI}(51.04354>3.433617)$. The $\mathrm{ADF}$ tests reject a unit root at the $5 \%$ significance level, therefore, we reject null hypothesis of unit roots against the alternative of stationarity at level.

In order to increase the robustness of the tests, the Phillips-Perron and the KPSS tests are carried out. The hypothesis for the ADF and the Phillips-Perron are the same. The test result for PP is presented in Table 3.

Table-3. Unit Root Test PP

\begin{tabular}{|c|c|c|c|c|}
\hline Variables & PP Test Statistics & Makinnon Critical Value@5\% & Prob. & Conclusion \\
\hline ACCES & -36.53841 & -2.862869 & 0.0000 & Reject \\
\hline DIAM & -77.72028 & -2.862869 & 0.0001 & Reject \\
\hline FIDE & -56.14167 & -2.862869 & 0.0001 & Reject \\
\hline FCMB & -47.16359 & -2.862869 & 0.0001 & Reject \\
\hline GTBB & -41.68274 & -2.862869 & 0.0000 & Reject \\
\hline STAM & -39.86895 & -2.862869 & 0.0000 & Reject \\
\hline SKYE & -56.98352 & -2.862869 & 0.0001 & Reject \\
\hline STER & -44.45286 & -2.862869 & 0.0001 & Reject \\
\hline UBAB & -37.78229 & -2.862869 & 0.0000 & Reject \\
\hline UNIO & -41.51167 & -2.862869 & 0.0000 & Reject \\
\hline UNIT & -62.44460 & -2.862869 & 0.0001 & Reject \\
\hline WEMA & -81.03781 & -2.862869 & 0.0001 & Reject \\
\hline ZENI & -51.63814 & -2.862869 & 0.0001 & Reject \\
\hline
\end{tabular}

Source: Author's Computation (2016) using E-view Statistical Package, version 7.0

Table 3 shows that the test statistics are all above the critical limits at 5\%, for ACCES $(-36.53841>-2.862869)$, DIAM (-77.72028 > -2.862869), FIDE(-56.14167> -2.862869), FCMB(-47.16359 > -2.862869), GTBB(-41.68274 $>-2.862869), \operatorname{STAM}(-39.86895>-2.862869)$, $\operatorname{SKYE}(-56.98352>-2.862869), \quad \operatorname{STER}(-44.45286>-2.862869)$, 
UBAB(-37.78229 > -2.862869), UNIO(-41.51167> -2.862869), UNIT( -62.44460 > -2.862869), WEMA(-81.03781 $>-2.862869)$ and ZENI(-51.63814 $>-2.862869)$. The ADF tests reject a unit root at the $5 \%$ significance level; therefore, we reject null hypotheses of unit roots against the alternative of stationarity at level.

The KPSS test works the other way around. It tests the null hypothesis of stationarity against the alternative of a unit root. The test result is presented in Table 4.

Table-4. Unit Root Test: KPSS

\begin{tabular}{l|l|l|l}
\hline Variables & KPSS Test Statistics & Makinnon Critical Value @ 5\% & Conclusion \\
\hline ACCES & 0.169844 & 0.463000 & Reject \\
\hline DIAM & 0.075795 & 0.463000 & Reject \\
\hline FIDE & 0.031495 & 0.463000 & Reject \\
\hline FCMB & 0.236417 & 0.463000 & Reject \\
\hline GTBB & 0.065273 & 0.463000 & Reject \\
\hline STAM & 0.074637 & 0.463000 & Reject \\
\hline SKYE & 0.114795 & 0.463000 & Reject \\
\hline STER & 0.093857 & 0.463000 & Reject \\
\hline UBAB & 0.088436 & 0.463000 & Reject \\
\hline UNIO & 0.132893 & 0.463000 & Reject \\
\hline UNIT & 0.049643 & 0.463000 & Reject \\
\hline WEMA & 0.133313 & 0.463000 & Reject \\
\hline ZENI & 0.094489 & 0.463000 & Reject \\
\hline Source: Author's Computation using E-view Statistical Package, version 7.0 &
\end{tabular}

It can be seen from Table 4 that KPSS test statistics are less than critical value at $5 \%$ significant level, suggesting that the changes in stock prices are stationary.

\section{Concluding Remarks}

Jarque Bera test was conducted to determine whether changes in stock prices are normally distributed or identically distributed random variables. The Jarque-Bera test statistics shows that null hypotheses of normality are rejected at $5 \%$ significance level. It means that changes in stock prices are not identically distributed random variables. The finding is at variance with the apiori expectation and weak form efficient market theory. The finding is consistent with Victor (2010) in Nigeria, who investigated weak form efficiency of Nigerian stock market and found that the NSE is inefficient in weak form.

The null hypothesis that there is a unit root in stock price changes was determined using ADF, PP and KPSS tests. At level, unit root is strongly rejected for all the stocks. Nigerian banking industry stocks do not show signs or evidences of random walk. The finding is at variance with the apiori expectation and weak form efficient market theory. The finding is consistent with Nwosa and Osheni (2011) in NSE which found based on the results of the PP and ADF that NSE is informational inefficient. The finding discloses that the Nigerian banking industry stock price changes does not follow a random walk. This implies that changes in stock prices do not follow the step of a man who is drunk and that Nigerian stock market is not efficient in weak form. This finding has implication for the regulatory authorities, investors, and market operators.

Also, the findings implies that there are certain factors which the investors and other market operators can study which affect stock price changes and that previous changes is one of those factors. This information is of vital importance to these categories of people who want to invest profitably and provide reliable investment advisory services to their clients. The finding reveals that changes in stock prices are not identically distributed random variables as put forth by the proponents of random walk hypothesis. The implication is that stock price changes are not determined by random events and that the changes can indeed be predicted. Since changes in stock prices are not indeterminable or caused by random events, the investor should endeavour to identify and study what determines the prices in the past in order to ensure judicious and prudent allocation of their investable funds.

\section{References}

Afego, P., 2012. Weak form efficiency of the Nigerian stock market: An empirical analysis (1984 - 2009). International Journal of Economics and Financial Issues, 2(3): 340-347. View at Google Scholar

Ajao, M.G. and R. Osayuwu, 2012. Testing the weak form of efficient market hypothesis in Nigerian capital market. Accounting and Finance Research, 1(1): 169-179. View at Google Scholar | View at Publisher

Aktham, M., 2003. The random walk hypothesis and the evidence from the Amman (Jordan) stock exchange. Zagreb International Review of Economics and Business, 6(1-2): 29-41. View at Google Scholar

Am'elie, C. and D. Olivier, 2009. The random walk hypothesis for Chinese stock markets: Evidence from variance ratio tests. Economic Systems, 33(2): 117-126. View at Google Scholar | View at Publisher

Bhanu, P. and T.R. Bishnoi, 2005. Testing random walk hypothesis for Indian stock market indices: 1-15.

Bodie, Z., A. Kane and J. Marcus, 2009. Investment. 8th Edn., New Yolk: McGraw Hill.

Emeh, Y. and J.O. Obi, 2014. Evaluation of the weak form of efficient market hypothesis: Empirical evidence from Nigeria. International Journal of Development and Sustainability, 3(5): 1199-1244.

Fama, E.F., 1965. Random walks in stock market prices. Financial Analysts Journal, 51(1): 75-80. View at Publisher

Godwin, C.O., 2010. Stock market prices and the random walk hypothesis: Further evidence from Nigeria. Journal of Economics and International Finance, 2(3): 049-057. View at Google Scholar

Graham, S. and R. Hyun-Jung, 2003. Variance ratio tests of the random walk hypothesis for European emerging stock markets. European Journal of Finance, 9(3): 290-300. View at Google Scholar | View at Publisher

Hussain, F., K. Hamid, R.S.I. Akash and M.I. Khan, 2011. Day of the week effect and stock returns: (Evidence from Karachi Stock ExchangePakistan). Far East Journal of Psychology and Business, 3(1): 25-31.

Ishaq, A.B., Q.M. Suhail and N.Z. Faisal, 2014. A comparative analysis of the efficiency of the stock markets of India and Pakistan. Global Journal of Finance and Management, 6(2): $117-124$. View at Google Scholar

Joel, O. and O.I. Sunday, 2015. Test of random walk hypothesis in the Nigerian stock market. Current Research Journal of Social Sciences, $7(2): 27-36$.

Kavalerchik, R., 2011. An Analysis of the Random Walk Hypothesis based on Stock Prices, Dividends, and Earnings. A Thesis Work. pp: 132 . 
Kendall, R., 1953. The analysis of economic time-series-part I: Prices. Journal of the Royal Statistical Society, 96(1): 11-34. View at Google Scholar $\mid$ View at Publisher

Lo, A.W. and A.C. MacKinlay, 1988. Stock market prices do not follow random walks: Evidence from a simple specification test. Review of Financial Studies, 1(1): 41-66. View at Google Scholar | View at Publisher

Mojekwu, J.N. and S. Ogege, 2013. Econometric investigation of the random walk hypothesis in the Nigerian stock market. Journal of Emerging Issues in Economics, Finance and Banking, 1(5): 381- 400. View at Google Scholar

Nwidobie, B.M., 2014. The random walk theory: An empirical test in the Nigerian capital market. Asian Economic and Financial Review, 4(12): 1840-1848. View at Google Scholar

Nwosa, P.I. and I.O. Osheni, 2011. Efficient market hypothesis and Nigerian stock market. Research Journal of Finance and Accounting, 2(12): 38-48. View at Google Scholar

Osisanwo, B.G. and A.A. Atanda, 2012. Determinants of stock market returns in Nigeria: A time series analysis. African Journal of Scientific Research, 9(1): 478-496. View at Google Scholar

Phillips, P.C. and P. Perron, 1988. Testing for a unit root in time series regression. Biometrika, 75(2): 335-346. View at Google Scholar | View at

Samuel, D., 2007. Why might share prices follow a random walk. Student Economic Review, 21(1): 167-179. View at Google Scholar

Victor, K.G., 2010. Testing the weak-form efficiency market hypothesis: Evidence from Nigerian stock market. CBN Journal of Applied Statistics, 3(1): 117-136.

Worthington, A.C. and H. Higgs, 2004. Random walks and market efficiency in European equity markets. Global Journal of Finance and Economics, 1(1): 59-78. View at Google Scholar

Yacout, M. and J.M. Samuels, 1981. Stock exchange in developing countries. Saving Develop, 5(4): 309-328. View at Google Scholar

\section{Bibliography}

www.capitalassets.ng.com. [Accessed February, 2016].

www.wikipedia. [Accessed 17-09-2015]. 